\title{
The effects of caffeic acid phenethyl ester on inflammatory cytokines after acute spinal cord injury
}

\author{
Hakan Ak, M.D., ${ }^{1}$ İsmail Gülşen, M.D., ${ }^{2}$ Tamer Karaaslan, M.D., ${ }^{3}$ İlker Alaca, M.D., ${ }^{3}$ \\ Aydın Candan, M.D., ${ }^{4}$ Havva Koçak, M.D., ${ }^{5}$ Tugay Atalay, M.D., ${ }^{1}$ \\ Asuman Çelikbilek, M.D., ${ }^{6}$ İsmail Demir, M.D., ${ }^{7}$ Tevfik Yılmaz, M.D. ${ }^{8}$
}

\begin{abstract}
1'Department of Neurosurgery, Bozok University Faculty of Medicine, Yozgat;
${ }^{2}$ Department of Neurosurgery, Yüzüncü Yıl University Faculty of Medicine, Van;

${ }^{3}$ Department of Neurosurgery, Süleyman Demirel University Faculty of Medicine, Isparta;

${ }^{4}$ Department of Histology and Embryology, Süleyman Demirel University Faculty of Medicine, Isparta;

${ }^{5}$ Department of Biocehmistry, Dumlupınar University Faculty of Medicine; Kütahya;

${ }^{6}$ Department of Neurology, Bozok University Faculty of Medicine, Yozgat;

${ }^{7}$ Department of Neurosurgery, Van Regional Training and Teaching Hospital, Van;

${ }^{8}$ Department of Neurosurgery, Dicle University Faculty of Medicine, Diyarbakır
\end{abstract}

\begin{abstract}
BACKGROUND: The purpose of this study was to investigate the effects of Caffeic Acid Phenethyl Ester (CAPE) on proinflammatory cytokines, IL-I $\beta$ and TNF- $\alpha$, and explore its healing effect after acute spinal cord injury.

METHODS: Forty-eight male Wistar-Albino rats were used in this study which was planned as three groups. All groups were divided into two sub-groups. Group la was the control group, in which only lower segment thoracic laminectomy was performed. In group Ib, spinal cord trauma was performed with aneurysm clip. In the second group, serum physiologic was given systemically thirty minutes after trauma, and rats were sacrificed after the first and sixth hour. In the third group, CAPE was given systemically thirty minutes after trauma, and rats were sacrificed after the first and sixth hour. Serum IL-I $\beta$ and TNF- $\alpha$ levels were analyzed by ELISA in the serum. Histopathological analysis was performed in damaged cord tissues.
\end{abstract}

RESULTS: CAPE suppressed TNF- $\alpha$ and IL-I $\beta$ levels in the serum. In histopathological evaluation, it was detected that CAPE decreased hemorrhage and necrosis.

CONCLUSION: CAPE suppresses the levels of proinflammatory cytokines, TNF- $\alpha$ and IL-I $\beta$, after acute spinal cord injury in the early phase and contributes to the healing process.

Key words: CAPE; IL-I $\beta$; inflammation; spinal cord injury; TNF- $\alpha$.

\section{INTRODUCTION}

Spine injury is a serious health problem having detrimental effects on the patient, family, and economy of the country.

Address for correspondence: Hakan Ak, M.D.
Bozok Üniversitesi Araştırma ve Uygulama Hastanesi,
66100 Yozgat, Turkey
$\begin{array}{ll}\text { Tel: }+90354 \text { - } 2127060 \text { / 367I } & \text { E-mail: nrsdrhakanak@yahoo.com } \\ \text { Qucik Response Code } & \text { Ulus Travma Acil Cerrahi Derg } \\ \end{array}$
$\begin{array}{ll}\text { 2015;2I(2):96-10I } \\ \text { doi: } 10.5505 / \text { tjtes.20I5.33848 }\end{array}$

Its general incidence is about $20-40 / 1.000 .000$ in many countries around the world. ${ }^{[I]}$ In the pathophysiology of acute spinal cord injury $(\mathrm{SCl})$, primary and secondary mechanisms of the injury have been proposed. There are four characteristic mechanisms in primary injury, which are impact plus persistent compression, impact alone with transient compression, distraction, and laceration/transaction. However, secondary mechanisms of injury, extending from primary injury, involve neurogenic shock, vascular insults, excitotoxicity, calciummediated secondary injury and fluid-electrolyte disturbances, immunologic injury, apoptosis, disturbances in mitochondrion function, and other miscellaneous processes. ${ }^{[2]}$

Caffeic acid phenethyl ester (CAPE) is one of the active components of propolis, which is a substance found in the plant extracts collected by honeybees. Antimicrobial, anti-inflam- 
matory, immunomodulatory, antimutagenic, and antioxidant effects of propolis have been revealed in several studies. CAPE, specifically by blocking NF- $\kappa B$ and oxygen radicals, inhibits many inflammatory agents, especially the TNF- $\alpha$. It has been shown that CAPE induces apoptosis in inflammatory cells independently from glucocorticoid receptors. Protective effects of CAPE in the nervous system have been reported in cerebral ischemic reperfusion injury, ischemic damage of the spinal cord, Parkinson's disease, convulsions, multiple sclerosis, brain tumors, hepatic encephalopathy, and against toxic effects of therapeutic agents in anticancer therapy. ${ }^{[3-}$ II] Moreover, studies evaluating its protective effect in spinal cord ischemia-reperfusion models and hemi-transection model have been reported; however, there is no study investigating the acute effects of CAPE in traumatic acute spinal cord injury in clip compression model. Therefore, this study was conducted to evaluate the early anti-cytotoxic effects of CAPE in acute spinal cord injury.

\section{MATERIALS AND METHODS}

After the approval of Süleyman Demirel University (SDÜ) Local Ethical Committee on Animal Experiments (12 153 I 123153855-136), surgical procedure was performed in the experimental animals' research laboratory of the medical faculty of the same university. Forty-eight Wistar albino adult male rats, weighing $250 \pm 40$ gr, were used. They were divided into three main groups, and each group was divided into two subgroups including eight animals. All animals were weighed before the operation and sacrification. Biochemical and pathological examinations were performed in the laboratories of biochemistry and histology-embryology departments of SDU.

In total, rats were divided into six groups;

Group Ia $(n=8)$ only laminectomy ( $\left.\left.\right|^{\text {st }} h\right)$,

Group Ib $(n=8)$ laminectomy + trauma $\left(I^{\text {st }} h\right)$,

Group $2 \mathrm{a}(\mathrm{n}=8)$ laminectomy + trauma + saline $\left(\mathrm{I}^{\text {st }} \mathrm{h}\right)$

Group $2 b(n=8)$ laminectomy + trauma + saline $\left(6^{\text {th }} h\right)$

Group 3a $(n=8)$ Laminectomy +trauma +CAPE $\left(\right.$ ( $\left.^{\text {st }} h\right)$

Group 3b $(n=8)$ Laminectomy + trauma +CAPE $\left(6^{\text {th }} h\right)$

\section{Anesthesia}

General anesthesia was achieved with an intraperitoneal administration of $8 \mathrm{mg} / 100 \mathrm{gr}$ ketamine (Alfamine 10\%, Ege Vet Hayvancılık Bornova-İzmir, Alfasan International BV Holland) and I mg/l00 gr xylazine (Alfazyne 2\%, Ege Vet Hayvancilık Bornova-İzmir, Alfasan International BV Holland).

\section{Surgical Procedure}

Laminectomy was performed between the thoracic vertebrae Th8 and Th 12. Aneurysm clip (Sugita no: 07-934-II, closure pressure: I.37-I.72 N) was used to create trauma for one minute (Figs la, b).

In Group Ia $(n=8)$, one hour after laminectomy, spinal cord tissues including lesion site and blood were taken for histopathological and biochemical evaluation before the rats were sacrificed with high dose of anesthesia. In Group Ib $(n=8)$, spinal cord tissues including lesion site and blood were taken one hour after laminectomy and trauma. In Group 2a $(n=8)$, Icc saline was given intraperitoneally thirty minutes after trauma. One hour after trauma, blood and spinal cord tissue were taken. In Group $2 b(n=8)$, the same steps as those of $2 \mathrm{a}$ were followed, but blood and tissue samples were taken six hours after trauma. In Group 3a $(n=8)$, CAPE was given intraperitoneally $(10 \mu g / k g)$ thirty minutes after trauma. One hour after trauma, blood and tissue samples were taken. In Group $3 b(n=)$, same dosage of CAPE was given intraperitoneally thirty minutes after trauma; however, blood and tissue samples were taken six hours later.

Interleukin I $\beta$ and tumor necrosis factor- $\alpha$ levels were measured in the blood with ELISA kits. For light microscopy, spinal cord tissue samples were fixed with $10 \%$ formalin.

\section{Statistical Analysis}

Statistical analyses were performed using SPSS 15.0 software (SPSS Inc., Chicago, IL, USA). Parametric values were given
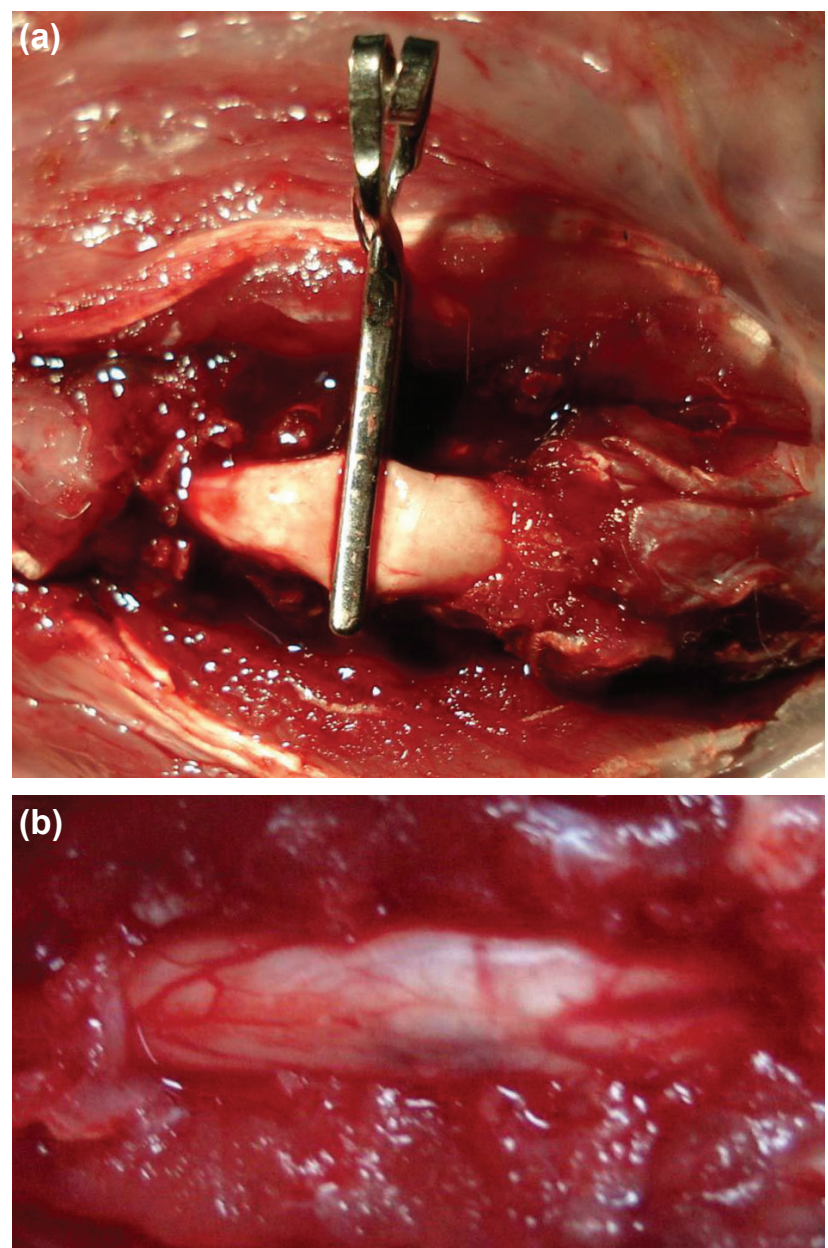

Figure 1. (a) Creating spinal cord injury with an aneurysm clip. (b) External view of spinal cord after creating injury. 
Table I. Mean TNF- $\alpha$ and IL-I $\beta$ values of each group

\begin{tabular}{ccc}
\hline & n & Mean \\
\hline TNF- $\alpha$ & & \\
Ia & 8 & 10.7798 \\
Ib & 8 & 13.0727 \\
$2 \mathrm{a}$ & 8 & $10.456 \mathrm{I}$ \\
$2 \mathrm{~b}$ & 8 & $10.07 \mathrm{II}$ \\
$3 \mathrm{a}$ & 8 & $9.23 \mathrm{II}$ \\
$3 \mathrm{~b}$ & 8 & 9.3185 \\
$\mathrm{IL}-\mathrm{I} \beta$ & & \\
$\mathrm{Ia}$ & 8 & 32.6550 \\
$\mathrm{Ib}$ & 8 & 33.8704 \\
$2 \mathrm{a}$ & 8 & 25.4870 \\
$2 \mathrm{~b}$ & 8 & 30.7100 \\
$3 \mathrm{a}$ & 8 & 23.8298 \\
$3 \mathrm{~b}$ & 8 & 21.1215 \\
\hline
\end{tabular}

as mean \pm standard deviation and non-parametric values were given as percentage. In order to compare parametric continuous variables, Student's t-test was used, and Mann-Whitney $U$-test was used to compare nonparametric continuous variables. Two-tailed $\mathrm{P}$-values of less than 0.05 were considered statistically significant.

\section{RESULTS}

\section{Biochemical Evaluation}

Mean serum TNF- $\alpha$ levels were $10.7798 \mathrm{pg} / \mathrm{ml}$ in Group Ia, | $3.0727 \mathrm{pg} / \mathrm{ml}$ in Group Ib, 10,456 pg/ml in Group 2a, 10.07 I | $\mathrm{pg} / \mathrm{ml}$ in Group 2b, 9.23 I I pg/ml in Group 3a, and 9.3185 pg/ $\mathrm{ml}$ in Group 3b (Table I). TNF- $\alpha$ levels were increased in Group Ib when compared to Group Ia; however, no statistically significant difference was observed $(p=0.070)$. There was not a statistically significant difference between Groups Ia, 2a, and $2 b(p=0.999$ and $p=0.949$, respectively). Similarly, there was not a significant difference between Groups Ia, 3a, and $3 b(p=0.404$ and $p=0.469$, respectively). Significant differences were detected between Groups Ib and Groups 2a or $2 b$, and Groups 3a and 3b $(p=0.026,0.007,0.001$, and 0.00I, respectively). No difference was observed between Groups 2, 3 and their subgroups (Table 2).

Mean serum IL-I $\beta$ levels were $32.6550 \mathrm{pg} / \mathrm{ml}$ in Group Ia, $33.8704 \mathrm{pg} / \mathrm{ml}$ in Group Ib, $25.4870 \mathrm{pg} / \mathrm{ml}$ in Group 2a, $30.7100 \mathrm{pg} / \mathrm{ml}$ in Group 2b, $23.8298 \mathrm{pg} / \mathrm{ml}$ in Group 3a, and $21.1215 \mathrm{pg} / \mathrm{ml}$ in Group 3b (Table I). IL-I $\beta$ level was decreased in Groups 3a and 3b when compared to Group Ib; however, no significant difference was observed between these groups ( $p=0.539$ and 0.278 , respectively). In addition, no statistically significant difference was detected between all groups and their subgroups (Table 3 ).

\section{Histological evaluation}

Stained tissue samples were examined under binocular microscope (Olympus BX50, NY), and microphotographs of the sections were evaluated.

For histopathological evaluation, a semi-quantitative scoring system which was previously used by Ercan et al. was selected. ${ }^{[12]}$ According to this system;

(-) score (negative score): no structural change

$(+)$ score (I positive score): slight changes.

$(++)$ score (2 positive score): moderate changes
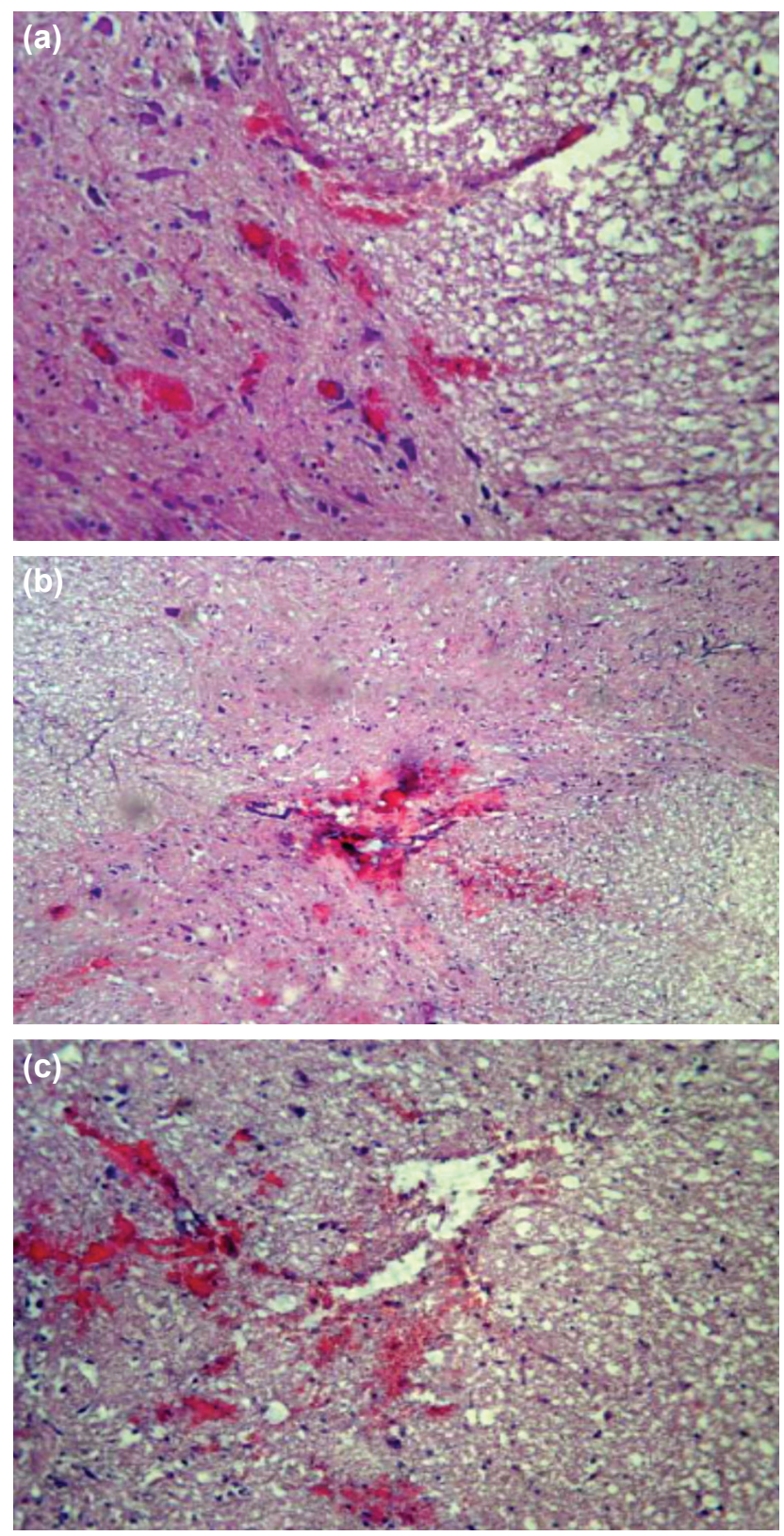

Figure 2. (a) Microscopic appearance in group 1a (H\&E, x100). (b) Microscopic appearance in group 2a (H\&E, x100). (c) Microscopic appearance in group $3 \mathrm{a}(\mathrm{H} \& \mathrm{E}, \mathrm{x100})$. 
Table 2. Statistical comparisons of TNF- $\alpha$ among the groups

\begin{tabular}{|c|c|c|c|}
\hline Dependant variable & (I) group & (J) group & $\mathbf{p}$ \\
\hline \multirow[t]{30}{*}{ TNF- $\alpha$} & la & $\mathrm{Ib}$ & 0.070 \\
\hline & & $2 a$ & 0.999 \\
\hline & & $2 b$ & .949 \\
\hline & & $3 a$ & .404 \\
\hline & & $3 b$ & .469 \\
\hline & $\mathrm{Ib}$ & la & .070 \\
\hline & & $2 a$ & .026 \\
\hline & & $2 b$ & .007 \\
\hline & & $3 a$ & .001 \\
\hline & & $3 b$ & .001 \\
\hline & $2 a$ & la & .999 \\
\hline & & $\mathrm{Ib}$ & .026 \\
\hline & & $2 b$ & .997 \\
\hline & & $3 a$ & .654 \\
\hline & & $3 b$ & .720 \\
\hline & $2 b$ & la & .949 \\
\hline & & $\mathrm{Ib}$ & .007 \\
\hline & & $2 a$ & .997 \\
\hline & & $3 a$ & .901 \\
\hline & & $3 b$ & .935 \\
\hline & $3 a$ & la & .404 \\
\hline & & $\mathrm{Ib}$ & .000 \\
\hline & & $2 a$ & .654 \\
\hline & & $2 b$ & .901 \\
\hline & & $3 b$ & 1.000 \\
\hline & $3 b$ & Ia & .469 \\
\hline & & $\mathrm{Ib}$ & .001 \\
\hline & & $2 a$ & .720 \\
\hline & & $2 b$ & .935 \\
\hline & & $3 a$ & 1.000 \\
\hline
\end{tabular}

Table 3. Statistical comparisons of IL-I $\beta$ among the groups

\begin{tabular}{|c|c|c|c|}
\hline Dependant variable & (I) group & (J) group & $\mathbf{p}$ \\
\hline \multirow[t]{30}{*}{ IL-I $\beta$} & la & $\mathrm{Ib}$ & 1.000 \\
\hline & & $2 a$ & .828 \\
\hline & & $2 b$ & .999 \\
\hline & & $3 a$ & .670 \\
\hline & & $3 b$ & .386 \\
\hline & $\mathrm{Ib}$ & la & 1.000 \\
\hline & & $2 a$ & .715 \\
\hline & & $2 b$ & .994 \\
\hline & & $3 a$ & .539 \\
\hline & & $3 b$ & .278 \\
\hline & $2 \mathrm{a}$ & $\mathrm{Ia}$ & .828 \\
\hline & & $\mathrm{Ib}$ & .715 \\
\hline & & $2 b$ & .948 \\
\hline & & $3 a$ & 1.000 \\
\hline & & $3 b$ & .976 \\
\hline & $2 b$ & Ia & .999 \\
\hline & & Ib & .994 \\
\hline & & $2 a$ & .948 \\
\hline & & $3 a$ & .851 \\
\hline & & $3 b$ & .588 \\
\hline & $3 a$ & la & .670 \\
\hline & & Ib & .539 \\
\hline & & $2 a$ & 1.000 \\
\hline & & $2 b$ & .851 \\
\hline & & $3 b$ & .997 \\
\hline & $3 b$ & la & .386 \\
\hline & & $\mathrm{lb}$ & .278 \\
\hline & & $2 a$ & .976 \\
\hline & & $2 b$ & .588 \\
\hline & & $3 a$ & 997 \\
\hline
\end{tabular}

Table 4. Histopathological findings of each group

\begin{tabular}{|c|c|c|c|c|}
\hline Group number & $\begin{array}{l}\text { Degeneration or hemorrhage } \\
\text { in central canal }\end{array}$ & $\begin{array}{l}\text { Necrosis in gray } \\
\text { and white matter }\end{array}$ & $\begin{array}{l}\text { Hemorrhage in gray } \\
\text { and white matter }\end{array}$ & Liquefaction necrosis \\
\hline Ia & - & + & + & - \\
\hline Ib & +++ & +++ & +++ & +++ \\
\hline $2 a$ & +++ & +++ & +++ & +++ \\
\hline $2 b$ & +++ & +++ & +++ & +++ \\
\hline $3 a$ & + & + & + & + \\
\hline $3 b$ & + & + & + & + \\
\hline
\end{tabular}


$(+++)$ score (3 positive score): prominent changes.

Group Ia: Slight hemorrhage was detected in gray and white matter (+). Also, slight necrosis was seen in both matters $(+)$. Degeneration, hemorrhage, and liquefaction necrosis were not observed in the central canal (Fig. 2a).

Group Ib: Prominent hemorrhage and necrosis were observed in both matters (+++). Also, degeneration, hemorrhage, and liquefaction necrosis were prominent in the central canal $(+++)$.

Group 2a: Prominent hemorrhage and necrosis were observed in both matters (+++). Also, degeneration, hemorrhage, and liquefaction necrosis were prominent in central canal $(+++)$ (Fig. 2b).

Group 2b: Similar findings were observed as those of Groups $\mathrm{Ib}$ and $2 \mathrm{a}$.

Group 3a: There was slight hemorrhage and liquefaction necrosis around central canal. Moderate hemorrhage and necrosis were observed in white and gray matter less than previous groups (Fig. 2c).

Group 3b: Similar findings were observed as those of Group 3a (Table 4).

\section{DISCUSSION}

In the present study, CAPE was detected to decrease TNF- $\alpha$ and IL-I $\beta$ levels after spinal cord injury in the early period. Furthermore, it reduces hemorrhage and necrosis in gray and white matter, as well as in the central canal.

Two known mechanisms of spinal cord injury are primary mechanical injury and secondary injury. Underlying mechanisms of pathophysiology in these injuries include acute hemorrhage, ischemia, inflammation, abnormal intracellular ion shifts $(\mathrm{Na}+, \mathrm{Ca}+2)$, lipid peroxidation of cell membrane induced by free radicals, edema, leukocyte infiltration, and excitotoxic cell death. ${ }^{[13]}$

Inflammation begins immediately after spinal cord injury. Edema, hemorrhage, accumulation of neuroexcitotoxin, and biochemical changes beginning after injury create difficulties on determining the main effects of inflammation on central nervous system. Although inflammation includes vascular, neurologic, humoral, and cellular responses around the injury site, it is a process to remove harmful stimuli and "contribute to tissue repair". ${ }^{[14]}$ The cellular source of IL-I $\beta$ and TNF- $\alpha$ after acute spinal cord injury is controversial. Some authors believe that these cytokines are the primary products of neutrophils and macrophages. However, other studies have shown that endogen central nervous system cells (microglia) secrete pro-inflammatory cytokines in many injury models. ${ }^{[15]}$
This study utilized CAPE which inhibits lipid peroxidation by suppressing protein tyrosine kinase, cyclooxygenase (nonspecifically), and lipoxygenase. Anti-inflammatory activity of CAPE was found equivalent with diclofenac and hydrocortisone. ${ }^{[16]}$ It has also been suggested that CAPE induces apoptosis independently from glucocorticoid receptors. ${ }^{[17]}$

The protective effects of CAPE have been practiced in various studies dealing with cerebral ischemia-reperfusion injury, spinal cord ischemia-reperfusion injury, Parkinson's disease, hypoxic ischemic brain damage in newborns, multiple sclerosis, convulsions, brain tumors, toxic effects of therapeutic agent in anticancer therapies, and hepatic encephalopathy. ${ }^{[3-1}$ I]

There are only five studies in the literature evaluating the effects of CAPE in the spinal cord. ${ }^{[5,8,11,18,19]}$ Two of these studies have been performed to evaluate the protective effects of CAPE against experimental allergic encephalomyelitisinduced oxidative stress, and in methotrexate administered rats. ${ }^{[8,11]}$ Kasai et al. have reported that CAPE might be a promising therapeutic agent for reducing secondary neural damage in their hemi-transection model. ${ }^{[18]}$ In the remaining two studies, researchers have evaluated the effects of CAPE in ischemia-reperfusion injury model. Authors have reported that CAPE decreases injury more than methylprednisolone with its antioxidant and anti-inflammatory effects. ${ }^{[5,19]}$ In the present study, clip compression model, which suits more to the trauma model in humans, was used. This is the first study evaluating the effects of CAPE in this model. Same dosage of CAPE $(10 \mu g / k g)$ with the previous reports was administered. It was found that CAPE decreased the levels of proinflammatory cytokines but not in significant levels, which may be due to the fact that the evaluation process was conducted in serum, not in tissue. This may be a limitation of our study.

\section{Conclusion}

CAPE decreases inflammation, necrosis and hemorrhage in the injured spinal cord tissue. It may become a promising agent in the management of spinal cord injury with further studies.

Conflict of interest: None declared.

\section{REFERENCES}

1. Selvarajah S, Hammond ER, Haider AH, Abularrage CJ, Becker D, Dhiman $\mathrm{N}$, et al. The burden of acute traumatic spinal cord injury among adults in the united states: an update. J Neurotrauma 2014;31:228-38.

2. Dumont RJ, Okonkwo DO, Verma S, Hurlbert RJ, Boulos PT, Ellegala $\mathrm{DB}$, et al. Acute spinal cord injury, part I: pathophysiologic mechanisms. Clin Neuropharmacol 2001;24:254-64. CrossRef

3. Khan M, Elango C, Ansari MA, Singh I, Singh AK. Caffeic acid phenethyl ester reduces neurovascular inflammation and protects rat brain following transient focal cerebral ischemia. J Neurochem 2007;102:365-77.

4. Tsai SK, Lin MJ, Liao PH, Yang CY, Lin SM, Liu SM, et al. Caffeic acid phenethyl ester ameliorates cerebral infarction in rats subjected to focal 
cerebral ischemia. Life Sci 2006;78:2758-62. CrossRef

5. Ilhan A, Koltuksuz U, Ozen S, Uz E, Ciralik H, Akyol O. The effects of caffeic acid phenethyl ester (CAPE) on spinal cord ischemia/reperfusion injury in rabbits. Eur J Cardiothorac Surg 1999;16:458-63. CrossRef

6. Noelker C, Bacher M, Gocke P, Wei X, Klockgether T, Du Y, et al. The flavanoide caffeic acid phenethyl ester blocks 6-hydroxydopamine-induced neurotoxicity. Neurosci Lett 2005;383:39-43. CrossRef

7. Wei X, Zhao L, Ma Z, Holtzman DM, Yan C, Dodel RC, et al. Caffeic acid phenethyl ester prevents neonatal hypoxic-ischaemic brain injury. Brain 2004;127(Pt 12):2629-35. CrossRef

8. Ilhan A, Akyol O, Gurel A, Armutcu F, Iraz M, Oztas E. Protective effects of caffeic acid phenethyl ester against experimental allergic encephalomyelitis-induced oxidative stress in rats. Free Radic Biol Med 2004;37:38694. CrossRef

9. Ilhan A, Iraz M, Gurel A, Armutcu F, Akyol O. Caffeic acid phenethyl ester exerts a neuroprotective effect on CNS against pentylenetetrazolinduced seizures in mice. Neurochem Res 2004;29:2287-92. CrossRef

10. Lin YH, Chiu JH, Tseng WS, Wong TT, Chiou SH, Yen SH. Antiproliferation and radiosensitization of caffeic acid phenethyl ester on human medulloblastoma cells. Cancer Chemother Pharmacol 2006;57:525-32.

11. Uzar E, Sahin O, Koyuncuoglu HR, Uz E, Bas O, Kilbas S, et al. The activity of adenosine deaminase and the level of nitric oxide in spinal cord of methotrexate administered rats: protective effect of caffeic acid phenethyl ester. Toxicology 2006;218:125-33. CrossRef

12. Ercan I, Cakir BO, Başak T, Ozbal EA, Sahin A, Balci G, et al. Effects of topical application of methotrexate on nasal mucosa in rats: a preclinical assessment study. Otolaryngol Head Neck Surg 2006;134:751-5. CrossRef

13. Zhang $\mathrm{N}$, Yin $\mathrm{Y}, \mathrm{Xu} \mathrm{SJ}, \mathrm{Wu} \mathrm{YP}$, Chen WS. Inflammation $\&$ apoptosis in spinal cord injury. Indian J Med Res 2012;135:287-96.

14. Beck KD, Nguyen HX, Galvan MD, Salazar DL, Woodruff TM, Anderson AJ. Quantitative analysis of cellular inflammation after traumatic spinal cord injury: evidence for a multiphasic inflammatory response in the acute to chronic environment. Brain 2010;133:433-47. CrossRef

15. Herx LM, Rivest S, Yong VW. Central nervous system-initiated inflammation and neurotrophism in trauma: IL-1 beta is required for the production of ciliary neurotrophic factor. J Immunol 2000;165:2232-9. CrossRef

16. Koksel O, Ozdulger A, Tamer L, Cinel L, Ercil M, Degirmenci U, et al. Effects of caffeic acid phenethyl ester on lipopolysaccharide-induced lung injury in rats. Pulm Pharmacol Ther 2006;19:90-5. CrossRef

17. Zaeemzadeh N, Hemmati A, Arzi A, Jalali M, Rashidi I. Protective Effect of Caffeic Acid Phenethyl Ester (CAPE) on Amiodarone-Induced Pulmonary Fibrosisin Rat. Iran J Pharm Res 2011;10:321-8.

18. Kasai M, Fukumitsu H, Soumiya H, Furukawa S. Caffeic acid phenethyl ester reduces spinal cord injury-evoked locomotor dysfunction. Biomed Res 2011;32:1-7. CrossRef

19. Sahin S, Sogut S, Ozyurt H, Uz E, Ilhan A, Akyol O. Tissue xanthine oxidase activity and nitric oxide levels after spinal cord ischemia/reperfusion injury in rabbits: comparison of caffeic acid phenethyl ester (CAPE) and methylprednisolone. Neuroscience Research Communications 2002;31:111-21. CrossRef

\section{DENEYSEL ÇALIŞMA - ÖZET}

\section{Kafeik asit fenetil esterin akut spinal kord hasarı sonrasinda enflamatuvar sitokinler üzerine etkisi}

\section{Dr. Hakan Ak, ${ }^{1}$ Dr. İsmail Gülşen, ${ }^{2}$ Dr. Tamer Karaaslan, ${ }^{3}$ Dr. İlker Alaca, ${ }^{3}$ Dr. Aydın Candan, ${ }^{4}$ Dr. Havva Koçak, ${ }^{5}$ Dr. Tugay Atalay, ${ }^{1}$ Dr. Asuman Çelikbilek, ${ }^{6}$ Dr. İsmail Demir, ${ }^{7}$ Dr. Tevfik Yılmaz ${ }^{8}$}

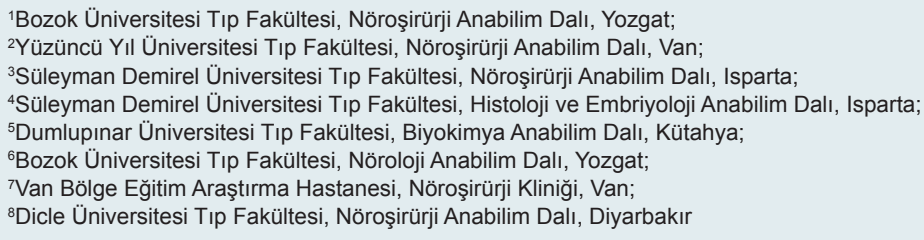

AMAÇ: Bu çalışmada, akut spinal kord hasarı sonrası erken dönemde kafeik asit fenetil esterin (KAFE) enflamatuvar sitokinlerden interlökin I beta (IL-I $\beta$ ) ve tümör nekrotizan faktor alfa (TNF- $\alpha$ ) üzerine etkisini ve histopatolojik olarak KAFE'nin olası iyileştirici etkisini araştırmak amaçlandı. GEREÇ VE YÖNTEM: Çalışmada ağırlıkları 250-300 gram arasında değişen 48 Wistar-Albino cinsi sıçan kullanıldı. Denekler üç gruba ayrıldı. Her grup kendi altında iki alt gruba ayrıldı. I grubu kontrol grubu olup bu grupta yalnızca laminektomi yapıldı. Grup Ib'de laminektomi sonrası anevrizma klibi ile travma oluşturuldu. İkinci gruptaki deneklerde travma oluşturulduktan yarım saat sonra serum fizyolojik sistemik olarak verilip birinci ve altıncı saatte denekler sakrifiye edildi. Üçüncü grupta travma oluşturulmuş deneklere yarım saat sonra sistemik yoldan KAFE verildi ve bu denekler birinci ve altıncı saatte sakrifiye edildi. Sakrifikasyon öncesi kalpten alınan kanda ELiSA kitleri ile serum IL- I $\beta$ ve TNF- $\alpha$ düzeyleri ölçüldü. Hasarlanmış kordan alınan doku örneklerinde histopatolojik değerlendirme yapıldı.

BULGULAR: Kafeik asit fenetil esterin verilen grupta TNF- $\alpha$ ve IL- I $\beta$ düzeylerinin azaldığı tespit edildi. Histopatolojik değerlendirmede KAFE verilen grupta hemoraji ve nekroz oranında azalma tespit edildi.

TARTIŞMA: Akut spinal kord hasarı sonrası erken dönemde KAFE enflamatuvar sitokinlerden TNF- $\alpha$ ve IL-I $\beta$ düzeylerini baskılamaktadır ve hasar sonrası iyileşmeye katkıda bulunmaktadır.

Anahtar sözcükler: Enflamasyon; interlökin- I $\beta$; kafeik asit fenetil ester; spinal kord hasarı; tümör nekrotizan faktör- $\alpha$.

Ulus Travma Acil Cerrahi Derg 2015;2I (2):96-10I doi: 10.5505/tjtes.2015.33848 